
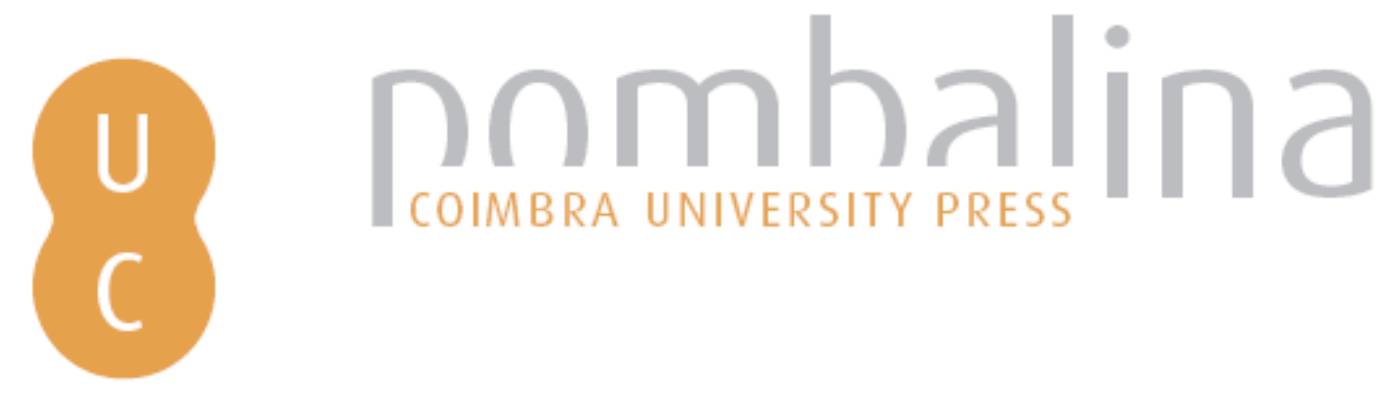

\title{
Institutional engagement and public involvement at the WUI: a case study in the South of Spain: Córdoba municipality
}

Autor(es): Quesada-Fernández, Clara; Quesada-Fernández, Daniel

Publicado por: Imprensa da Universidade de Coimbra

URL

persistente: URI:http://hdl.handle.net/10316.2/44691

DOI: $\quad$ DOI:https://doi.org/10.14195/978-989-26-16-506_174

Accessed : $\quad$ 26-Apr-2023 11:50:16

A navegação consulta e descarregamento dos títulos inseridos nas Bibliotecas Digitais UC Digitalis, UC Pombalina e UC Impactum, pressupõem a aceitação plena e sem reservas dos Termos e Condições de Uso destas Bibliotecas Digitais, disponíveis em https://digitalis.uc.pt/pt-pt/termos.

Conforme exposto nos referidos Termos e Condições de Uso, o descarregamento de títulos de acesso restrito requer uma licença válida de autorização devendo o utilizador aceder ao(s) documento(s) a partir de um endereço de IP da instituição detentora da supramencionada licença.

Ao utilizador é apenas permitido o descarregamento para uso pessoal, pelo que o emprego do(s) título(s) descarregado(s) para outro fim, designadamente comercial, carece de autorização do respetivo autor ou editor da obra.

Na medida em que todas as obras da UC Digitalis se encontram protegidas pelo Código do Direito de Autor e Direitos Conexos e demais legislação aplicável, toda a cópia, parcial ou total, deste documento, nos casos em que é legalmente admitida, deverá conter ou fazer-se acompanhar por este aviso.

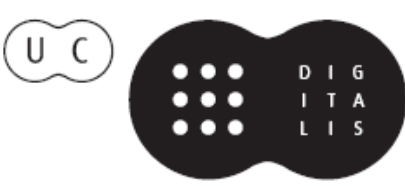




\section{ADVANCES IN}

\section{FOREST FIRE RESEARCH}

\section{8}

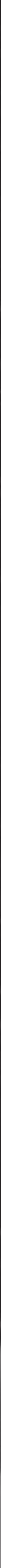


Short contribution - Fire at the Wildland Urban Interface

Institutional engagement and public involvement at the WUI. A case study in the South of Spain: Córdoba municipality

\author{
Clara Quesada-Fernández ${ }^{1 *}$; Daniel Quesada-Fernández ${ }^{2 *}$ \\ ${ }^{I}$ University of Córdoba. Spain. \{claraquesada@gmail.com*, z32quefec@uco.es*\} \\ ${ }^{2}$ Consultant, \{danielquesadafernandez@gmail.com\}
}

Keywords: Córdoba, civic engagement, fire regulation, fire prone areas, fuels management, institutional and public involvement, safety, perception, risk, safety, Spain, social involvement, wildland firefighters, wildland fires, wildland urban interface.

\title{
1. Introduction \& antecedents
}

There are numerous cases of emergencies in fire prone and wildland urban interface areas that have occurred during the last years, with an exponential growth as time goes by. In Spain most of the situations were declared level 2 (out of a maximum of 3), fires endangering seriously people and properties- according to the current Basic Civil Protection Directive.

Some close examples, all of them recognizable by the media, occurred last year. We must remember numerous cases where populations were affected and dramatic fire situations with thousands of evacuated and killed people (Doñana National Park-Spain, Encinedo-León, Galicia, Tejeda-Gran Canaria, Pedrógão Grande, Coimbra, Valença, Sertã, Viana do Castelo, Braga, Viseu and Monção in Portugal; Var, Bouches-du-Rhone and Vaucluse, Corsica, Marseille and Nice in France; Campania, Calabria, Puglia, Tuscany, Lazio, Sicily and Sardinia, Enna, Messina and Palermo in Italy; Athens, in Greece; Valparaíso, in Chile; Los Angeles, in California).

\section{Córdoba municipality}

The reality of the municipality of Córdoba was included in 2011 in the PYROSUDOE European Project focused on forest fire risk perception in the southeast and southwest of the Mediterranean WUI areas. The general objective was the characterization of WUI municipalities of Córdoba and Almodóvar del Río. It consisted on a preliminary study on fire reality at WUI areas and their associated risks reflecting, analyzing and proposing a basic action guide for preventive purposes and future applications. The specific objective of the work was to review the territory In order to characterize and distribute the WUI situations in the municipalities of Córdoba and Almodóvar del Río, and their risks associated with forest fires.

A diagnosis of the urban-forest interface was obtained in relation to the risk associated with forest fire episodes, identifying the types of interfaces, estimating the associated vulnerability, obtaining cartography of the distribution and incorporating this study into the calculation of fire risk.

The municipality of Córdoba (Spain) is one of the largest municipalities in the homonymous province. Within its area of $1,255 \mathrm{~km} 2$ the presence of areas of wildland urban interface is widespread and the occupation of the territory with this spatial

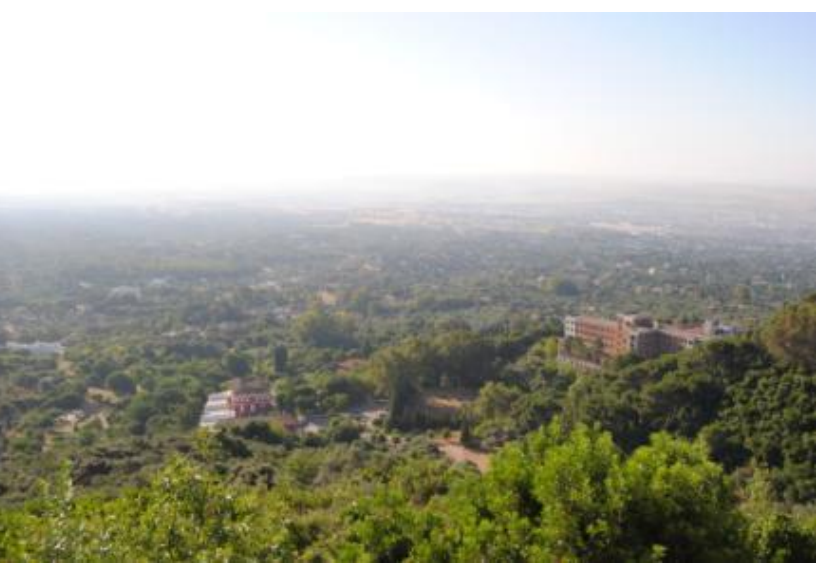

Figure 1 - The reality of the municipality of Córdoba (Spain) seen from the North of the city. 
structure is extensive. In recent years, urban expansion in forestry has entailed a new problem such as the scenario of forest fires near or within urban settlements. To the techniques and protocols for fire suppression, often limited in these environments, it is necessary to add those of civil protection since people, properties and infrastructures are threatened and affected by fires and smoke.

\section{The forest, territorial and fire regulations}

The present fuels, which are no longer only of a vegetable / forestry nature, as well as the infinite combination of possible situations, make it difficult to work in these areas. The suppression in the WUI needs, therefore, an adaptation of the current Incident Command System, that is, the way in which the operation is organized in the intervention. It must be adapted to the emergency in which it is not possible to rely on the generalized application of the same attack techniques that have been used until in previous interventions. From current legislation it is necessary to question whether the current texts are sufficient and are updated enough to deal with the problem in a practical and problem solving way. In this sense we should consider the validity of the current Basic Guideline for Emergency Civil Protection Planning for Forest Fires, (RD 893/2013), the current State Forestry Law 43/2003, the autonomous articles as well as the provincial and municipal ones.

\section{Institutional engagement and public involvement at the WUI.}

The Consejería de Medio Ambiente y Ordenacion del Territorio, Regional and local forest Administration, are trying to communicate to people a forest culture in terms of the proper use of fire and its implication in a context of urban-based communites in the areas of the municipality. Fuels management in WUI zones (private and public lands) and public information (residents and scholars) are considered as essential matter and they are welcomed by residents and general public.

\subsection{Fuels management in WUI zones.}

This action it is focused on three types of action areas depending on the distance between structures and fuels. It is considered location of the structures as well as actual fuels structure versus future structure after management of them and the type of action in each one.

Fuels management depends on priority zones Priority $1(0-10 \mathrm{~m})$, Priority $2(10-30 \mathrm{~m})$ and Priority $3(30-100 \mathrm{~m})$. It is also regulates the fuels management around power lines

Fuels elimination is made following fire regulations and it depends on the moment of year in which they are generated. The can be eliminated using fire under and strict observance of weather and public occupation in forest areas.

\subsection{Public information}

Residents in WUI areas in the municipality of Córdoba receive annual information regarding to fire uses, fire regulations and which implications of a bad use of fire could affect (more) negatively on wildland firefighters operations and safety.

In early ages the "Crece con tu árbol" ("Growing up beside your tree") andalusian programme has created and educational context in terms of culture of fire use by visiting primary and secondary schools in the municipality.

\section{Conclusions}

Forest forestry and forest fire prevention in forestry so far had been based on the so-called classical forestry actions such as the repopulation of areas affected by fires or diseases, the repair of roads and hydrological correction combined with a reasonable use of fire in order to use and exploit the forest biomass generated and available in the forest. 
However, changes in social uses have compromised the maintenance of our forests and the involvement of the population with them. In these new realities and from the operational point of view and intervention in the emergency, new strategies and new tactics of struggle and suppression are imposed. In that sense we should consider what happens with territorial planning policies, why we have reached these realities and what solution(s) can be given. The combination of possibilities and territorial variety of forms of the problem leave numerous examples that illustrate the problem of an emergency in the urban-forest interface. It is in these moments in which one considers how to act in such a reality.

We highly appreciate the collaboration of Consejería de Medio Ambiente y Ordenación del Territorio (Junta de Andalucía, España (Regional Forest Administration) through Centro Operativo Provincial (Córdoba) (Province Wildland Fire Operations Center) and we would like to thank all its members.

\section{Bibliography}

Luque Marín, Iván: 2015. Experiencias en municipios con aplicación de regulaciones y recomendaciones: Córdoba. I Seminario sobre actuaciones de prevención, seguridad y extinción en zonas de interfaz urbano-forestal. Colegio de Ingenieros Técnicos Forestales. San Fernando de Henares, 12 de noviembre de 2015.

Quesada Fernández, Clara: "Formación y capacitación técnica de profesionales para la gestión de la interfaz y la prevención” I Seminario sobre actuaciones de prevención, seguridad y extinción en zonas de interfaz urbano-forestal. Colegio de Ingenieros Técnicos Forestales. San Fernando de Henares, 12 de noviembre de 2015.

Quesada Fernández, Clara: Oportunidades, limitaciones y retos de seguridad en la defensa y combate de incendios en la interfaz urbano forestal. V Congreso Científico de Investigadores en Formación de la Universidad de Córdoba, "Creando redes", 2016.

Quesada Fernández, Clara y Quesada Fernández, Daniel: Fire Culture and Environmental Education in Fire Prone Communities' Areas: State of the Art and Case Study in Spain en Proceedings of the the IV International symposium on fire economics, policy and planning: climate change and fire. 5-11 de noviembre de 2012, Ciudad de Méjico (Méjico), USDA Forest Service, Riverside, California, 2012.

Quesada Fernández, Clara y Quesada Fernández, Daniel: Perception du risque dans les petites communautés sujette au feu. Etude de cas (Fire risk perception in fire prone communities. Case of Cerro Muriano, (Córdoba, Spain) en International Conference on forest fire risk modelling and mapping. 30 de septiembre - 2 de octubre de 2013. Aix en Provence (Francia), IRSTEA, 2013.

Quesada Fernández, Clara y Quesada Fernández, Daniel: Safety at the WUI: a firefighters view en Viegas (ed.), Advances in Forest Fires Research, Coimbra, Press Coimbra, 2014.

Quesada Fernández, Clara y Quesada Fernández, Daniel: Residents perception of forest fire risk at WUI. Study cases in northwestern Andalusia (Spain) en II International Conference on Fire Behaviour and Risk (Alghero, Cerdeña, Italia), 2015.

Quesada Fernández, Clara y Quesada Fernández, Daniel: Wildland urban interface: Wildland Firefighting Safety Problems and Challenges en $14^{\text {th }}$ International Summit on Fire Safety. Barcelona (España), 2017.

Quesada Fernández, Clara, Quesada Fernández, Daniel, Luque, I. 2016. Opportunities to prevent fires in early ages. A mediterranean example: "Crece con tu Árbol" ("Growing up beside your tree”) andalusian programme. FORESTFIRE 2016. International Conference on Forest Fires and WUI Fires. Aix en Provence (Francia), IRSTEA, 2016. 